\title{
The Treatment of Used Reagent Glass Bottles Using Solidification Technology
}

\author{
Anggun Farida ${ }^{1, *}$, Iwan Juwana ${ }^{1}$, and Hazairin ${ }^{2}$ \\ ${ }^{1}$ Environmental Engineering Department, Institut Teknologi Nasional (Itenas), 40123 Bandung, Indonesia \\ ${ }^{2}$ Civil Engineering Department, Institut Teknologi Nasional (Itenas), 40123 Bandung, Indonesia
}

\begin{abstract}
Used reagent glass bottles are solid waste that people rarely pay attention to in Indonesia. In many cases, the bottles are disposed off without proper handling and treatment, due to the lack of research and information. One potential treatment for such waste is to transform the glass bottles into raw materials for concretes. The objective of the research is to determine the influence of crushed glass particles to the quality of the concrete. The potential reduction of glass bottles will also be calculated.The glass bottles used in this research are the amber ones. The concrete was designed to meet the K225 type requirements. Experiments were done using $0 \%, 25 \%$, $50 \%$, and $75 \%$ of crushed glass particles. In the concrete production, these crushed glass particles will replace the coarse aggregates. This research measured compressive strength and Toxicity Characteristic Leaching Procedures (TCLP) tests in accordance to SNI and TCLP Extraction Procedures from BAPEDAL. At the end, it was found that the concretes using all variations meet the requirements. As for the TCLP, it showed that concentrations of $\mathrm{Cr}^{6+}$ for the concretes using all variations were all under the threshold, according to Hazardous National Regulation 101/2014. The potential reduction is 600 - 2100 waste bottles.
\end{abstract}

\section{Introduction}

Waste is the residue of a human and animal activity and/or production process in solid, liquid, or gasses form [8]. Hazardous waste is the waste from a work and/or activity that contains hazardous materials. The reduction of such waste can be done through waste treatment and/or reuse $[2,8]$.

People are rarely concerned about solid hazardous waste from laboratory activity including used reagent glass bottles. If such waste are disposed off without proper handling and treatment, they will damage the environment and endanger human health. Thus, hazardous waste management is required for reducing such wastes. According to Republic of Indonesia's Government Regulation Number 101 of 2014 Regarding Hazardous and Toxic Waste Management, hazardous waste treatment is the processes undertaken to reduce the toxicity of waste. Stabilization and solidification are the alternatives of hazardous waste treatments that can be done to reduce the toxicity of waste [8]. Solidification using cement are the most common process. It is a process that physically encapsulates the contaminant by using portland cement $[7,14]$, which will be done in this research. Coarse aggregates, as raw materials to produce concrete, will be replaced by crushed brown glass particles with different concentration. Then, the concrete will undergo two tests: the compressive strength and TCLP tests. The materials in this research were used reagent glass bottles because of its abundance in every laboratory and have not been recycled

Up to this stage, research on concrete and concrete materials has been widely reported, and the effects of raw materials subtitution to the produced concrete have been described [1, 4, 10-15]. The use of waste glass in concrete materials has attracted wide attention. The waste glass addition is believed to have effect on the concrete compressive strength. Suhartini (2014) showned that $2,5 \%$ of crushed green glass bottles used to subtitute fine aggregate has increased concrete compressive strength. However, the subtitution of fine aggregates by $5 \%-10 \%$ has decreased its compressive strength. Hadi's research also showed that $25 \%-100 \%$ of coarse aggregates weight substituted by crushed green glass bottles has decreased its concrete compressive strength $[4,12]$.

Compressive strength is the capacity of a material or structure to withstand loads and causes the sample to be destroyed when loaded with a certain force [6]. Compressive strength is affected by the age of the concrete. Usually, concretes were tested after 28 days of castings [3]

This research aims to determine the effects of glass bottles waste addition on its compressive strength, TCLP quality, and the number of bottles that can be reduced due to these activities.

Corresponding author: anggunfrd@gmail.com 


\section{Materials and Methods}

\subsection{Glass Bottles}

Samples in this experiment were used reagent glass bottles. These glass particles will substitute the coarse aggregate in concrete production. The bottles were washed and crushed to meet the same size of coarse aggregates. The size of crushed glass particles were in the range of 4,75 and $19 \mathrm{~mm}$. As many as 25 brown glass bottles were obtained from X Water Laboratory, also known as "amber glass". The detailed characteristics of glass bottles used can be seen in Table 1 and 2, as well as in Figure 1.

Table 1. Chemical substances on glass bottles and the number of glass bottles.

\begin{tabular}{|c|c|c|c|}
\hline No. & $\begin{array}{c}\text { Chemical } \\
\text { Subtances }\end{array}$ & $\begin{array}{c}\text { The } \\
\text { Number } \\
\text { of Glass } \\
\text { Bottles } \\
\text { Used }\end{array}$ & $\begin{array}{c}\text { Volume } \\
\text { for 1 } \\
\text { Bottle } \\
\text { (ml) }\end{array}$ \\
\hline $\mathbf{1}$ & $\begin{array}{c}\text { G Solution } \\
\text { Reagent for } \\
\text { COD Meters) }\end{array}$ & 3 & 500 \\
\hline $\mathbf{2}$ & $\mathrm{KMnO}_{4} 0,05 \mathrm{~N}$ & 1 & 2500 \\
\hline $\mathbf{3}$ & $\begin{array}{c}\mathrm{K}_{2} \text { Cr } \mathrm{O}_{7} \text { 0,025 } \\
\text { N }\end{array}$ & 1 & 1000 \\
\hline $\mathbf{4}$ & $\begin{array}{c}\text { Potassium } \\
\text { Dichromate }\end{array}$ & 3 & 500 \\
\hline $\mathbf{5}$ & Chlution & 3 & 2500 \\
\hline $\mathbf{6}$ & Nitric Acid & 2 & 2500 \\
\hline $\mathbf{7}$ & Sulphuric Acid & 8 & 2500 \\
\hline $\mathbf{8}$ & $\begin{array}{c}\text { Hydrochloric } \\
\text { Acid }\end{array}$ & 3 & 2500 \\
\hline
\end{tabular}

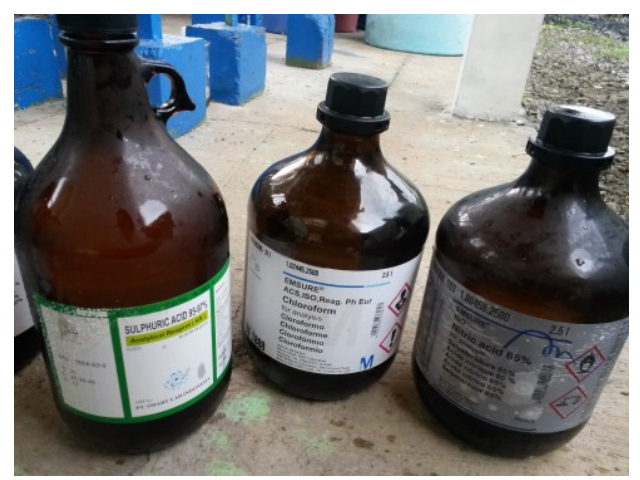

Figure 1. Some glass bottles were used for this research.
Table 2. The weight of glass bottles.

\begin{tabular}{|c|c|c|}
\hline No. & $\begin{array}{c}\text { Volume } \\
\text { (ml) }\end{array}$ & $\begin{array}{c}\text { Glass } \\
\text { Bottles } \\
\text { Weight (kg) }\end{array}$ \\
\hline $\mathbf{1}$ & 500 & 0,26 \\
\hline $\mathbf{2}$ & $\begin{array}{c}2500 \\
\text { (round } \\
\text { glass } \\
\text { bottles) }\end{array}$ & 1,17 \\
\hline $\mathbf{3}$ & 2500 & 1,01 \\
\hline $\mathbf{4}$ & 1000 & 1,2 \\
\hline
\end{tabular}

The parameters to be tested by TCLP were obtained from the chemical substances/reagents data and required parameters of relevant regulations. Then, the weight of glass bottles data in Table 2 was used to calculate the potential reduction of glass bottles waste in this particular laboratory.

\subsection{Experimental Methods}

Weight of each materials were obtained from concrete mix design based on SNI $03-2834-2000$. For this research, 8 cylinder concretes were created for each variations of mix. A total of 32 cylinder concretes for 4 variations were created as samples for this study.

For mix design result, materials weight for normal concrete is given in Table 3 . And the materials for each variation were obtained from mix design. Besides that, cylinder concrete diameter and height in this research were $10 \mathrm{~cm}$ and $20 \mathrm{~cm}$. Density of normal concrete is $2200-2600 \mathrm{~kg} / \mathrm{m}^{3}$. Weight of concrete can be obtained from volume of concrete and density of concrete. The result is given also in Table 3 .

Table 3. Quantity of Concrete

\begin{tabular}{|c|c|c|c|c|}
\hline $\begin{array}{c}\text { Fine } \\
\text { aggregates } \\
\text { weight } \\
\left(\mathbf{k g} / \mathbf{m}^{3}\right)\end{array}$ & $\begin{array}{c}\text { Coarse } \\
\text { aggregates } \\
\text { weight } \\
\left(\mathbf{k g} / \mathbf{m}^{3}\right)\end{array}$ & $\begin{array}{c}\text { Water } \\
\text { weight } \\
\left(\mathrm{kg} / \mathrm{m}^{3}\right)\end{array}$ & $\begin{array}{c}\text { Cement } \\
\text { weight } \\
\left(\mathrm{kg} / \mathrm{m}^{3}\right)\end{array}$ & $\begin{array}{c}\text { Weight } \\
\text { of } \\
\text { Concrete } \\
\text { (kg) }\end{array}$ \\
\hline 401,79 & 769,21 & 978,99 & 225 & 3768 \\
\hline
\end{tabular}

This experiment were carried out in Itenas Concrete and Pavement of Roads Laboratory and $\mathrm{X}$ Water Laboratory. The design of experiment is given in Table 4.

Table 4. Design of experiment and materials weight for each variation

\begin{tabular}{|c|c|c|c|c|}
\hline $\begin{array}{c}\text { Variation of glass } \\
\text { particles added } \\
(\%)\end{array}$ & $\mathbf{0 \%}$ & $\mathbf{2 5 \%}$ & $\mathbf{5 0 \%}$ & $\mathbf{7 5 \%}$ \\
\hline $\begin{array}{c}\text { Fine aggregates } \\
\text { weight (kg) }\end{array}$ & 10,62 & 10,62 & 10,62 & 10,62 \\
\hline $\begin{array}{c}\text { Coarse aggregates } \\
\text { weight (kg) }\end{array}$ & 13,53 & 10,15 & 6,77 & 3,38 \\
\hline
\end{tabular}




\begin{tabular}{|c|c|c|c|c|}
\hline $\begin{array}{c}\text { Variation of glass } \\
\text { particles added } \\
\text { (\%) }\end{array}$ & $\mathbf{0 \%}$ & $\mathbf{2 5 \%}$ & $\mathbf{5 0 \%}$ & $\mathbf{7 5 \%}$ \\
\hline Glass weight (kg) & 0 & 3,38 & 6,77 & 10,15 \\
\hline Water weight (kg) & 3,11 & 3,11 & 3,11 & 3,11 \\
\hline $\begin{array}{c}\text { Cement weight } \\
\text { (kg) }\end{array}$ & 5,55 & 5,55 & 5,55 & 5,55 \\
\hline TOTAL (kg) & $\mathbf{4 2 , 5 1}$ & $\mathbf{3 3 , 8 3}$ & $\mathbf{2 0 , 3}$ & $\mathbf{2 2 , 2}$ \\
\hline
\end{tabular}

\section{Results and Discussion}

\subsection{Slump Test}

Slump test measures the consistency of fresh concrete. The test is carried out using Abrams cone filled with fresh concrete in three stages. The slump test are illustrated in Figure 2 and the results of slump test are provided in Table 5 .

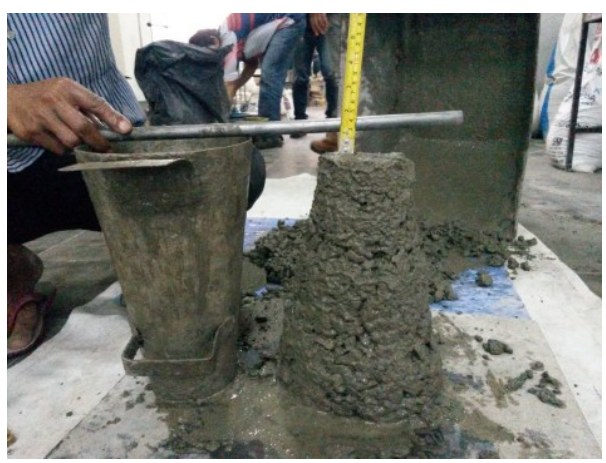

Figure 2. Slump test.

Table 5. The result of slump test.

\begin{tabular}{|c|c|c|c|c|}
\hline \multirow{2}{*}{$\begin{array}{c}\text { Variation } \\
\text { of } \\
\text { Crushed } \\
\text { Glass } \\
\text { Particles } \\
\text { Added }\end{array}$} & \multicolumn{2}{|c|}{ Date } & \multirow{2}{*}{$\begin{array}{c}\text { Concrete } \\
\text { Age } \\
\text { (days) }\end{array}$} & $\begin{array}{c}\text { Slump } \\
\text { (cm) }\end{array}$ \\
\cline { 2 - 3 } & Production & Test & & \\
\hline $\mathbf{0 \%}$ & $\begin{array}{c}\text { May 24, } \\
2016\end{array}$ & $\begin{array}{c}\text { June 21, } \\
2016\end{array}$ & 28 & 6,4 \\
\hline $\mathbf{2 5 \%}$ & $\begin{array}{c}\text { May 25, } \\
2016\end{array}$ & $\begin{array}{c}\text { June 22, } \\
2016\end{array}$ & 28 & 5 \\
\hline $\mathbf{5 0 \%}$ & $\begin{array}{c}\text { May 26, } \\
2016\end{array}$ & $\begin{array}{c}\text { June 23, } \\
2016\end{array}$ & 28 & 4,5 \\
\hline $\mathbf{7 5 \%}$ & $\begin{array}{c}\text { May 26, } \\
2016\end{array}$ & $\begin{array}{c}\text { June 23, } \\
2016\end{array}$ & 28 & 3 \\
\hline
\end{tabular}

It can be seen that the use of waste glass particles in the production of concrete decreases the slump value [11]. The decrease were due to the diameter of the crushed glass particles which were smaller than those of the coarse aggregates. Hence, more water is needed in the concrete production, because crushed bottle particle's surface area were larger than that of the coarse aggregate. In consequence, the slump value decreases with the increasing amount of crushed bottles particles

The slump concrete will take various shapes, in accordance to concrete mix. A collapse shape generally means that the mix is too wet because of the high slump value. High workability mix can influence the concrete production. If the concrete mixes were too dry, it will be difficult to work with.

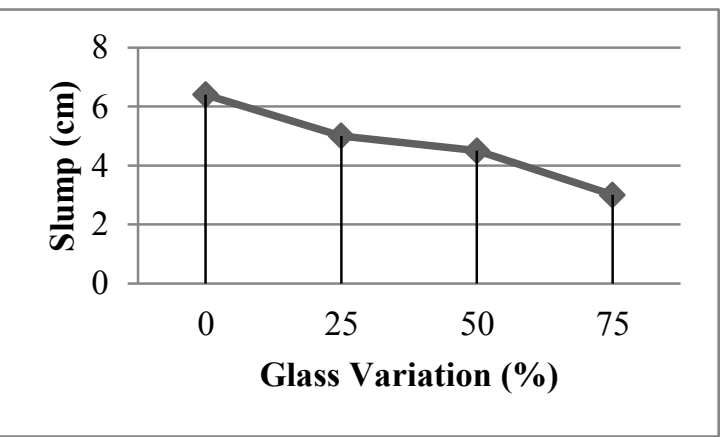

Figure 3. Influence of glass variation added on slump value.

\subsection{Compressive Strength}

All cylinder concretes were tested using a Universal Testing Machine (UTM). The concretes were tested after 28 days of castings, allowing the concretes to reach $99 \%$ of its strength. The concrete compressive strength test is illustrated in Figure 3 and the results are shown in Table 5 .

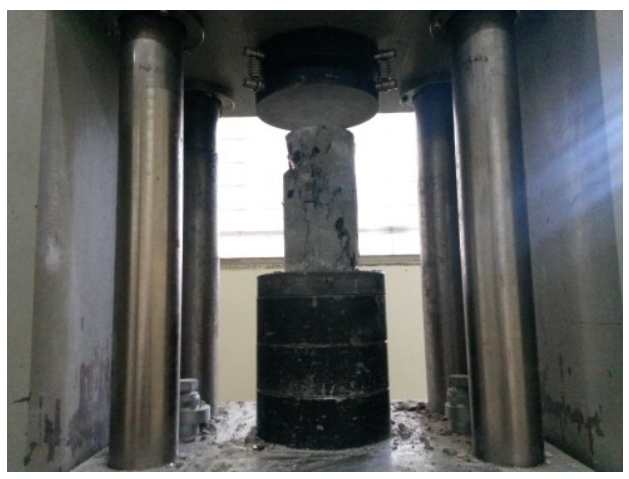

Figure 4. Compressive test.

Table 6. The result of compressive strength test.

\begin{tabular}{|c|c|c|c|c|}
\hline \multirow{2}{*}{$\begin{array}{c}\text { Variation } \\
\text { of } \\
\text { Crushed } \\
\text { Glass } \\
\text { Particles } \\
\text { Added }\end{array}$} & \multicolumn{2}{|c|}{ Date } & \multirow{2}{*}{$\begin{array}{c}\text { Compressi } \\
\text { ve } \\
\text { Strength } \\
\left(\mathbf{k g} / \mathrm{cm}^{2}\right)\end{array}$} & \multirow{2}{*}{$\begin{array}{c}\text { Compress } \\
\text { ive } \\
\text { Strength } \\
\text { (MPa) }\end{array}$} \\
\hline & Production & Test & & \\
\hline \multirow{5}{*}{$0 \%$} & \multirow{5}{*}{$\begin{array}{c}\text { May } 24, \\
2016\end{array}$} & \multirow{5}{*}{$\begin{array}{c}\text { June } 21, \\
2016\end{array}$} & 278,9 & 27,89 \\
\hline & & & 245,6 & 24,56 \\
\hline & & & 314 & 31,4 \\
\hline & & & 273,2 & 27,32 \\
\hline & & & 305,5 & 30,55 \\
\hline
\end{tabular}




\begin{tabular}{|c|c|c|c|c|}
\hline \multirow{2}{*}{$\begin{array}{c}\text { Variation } \\
\text { of } \\
\text { Crushed } \\
\text { Glass } \\
\text { Particles } \\
\text { Added } \\
\end{array}$} & \multicolumn{2}{|c|}{ Date } & \multirow{2}{*}{$\begin{array}{c}\text { Compressi } \\
\text { ve } \\
\text { Strength } \\
\left(\mathbf{k g} / \mathrm{cm}^{2}\right)\end{array}$} & \multirow{2}{*}{$\begin{array}{l}\text { Compress } \\
\text { ive } \\
\text { Strength } \\
\text { (MPa) }\end{array}$} \\
\hline & Production & Test & & \\
\hline \multicolumn{3}{|c|}{ Average of Compressive Strength } & 283,44 & 28,34 \\
\hline \multirow{5}{*}{$25 \%$} & \multirow{5}{*}{$\begin{array}{c}\text { May 25, } \\
2016\end{array}$} & \multirow{5}{*}{$\begin{array}{c}\text { June } 22, \\
2016\end{array}$} & 213,8 & 21,38 \\
\hline & & & 227,9 & 22,79 \\
\hline & & & 238 & 23,8 \\
\hline & & & 213 & 21,3 \\
\hline & & & 224 & 22,4 \\
\hline \multicolumn{3}{|c|}{ Average of Compressive Strength } & 223,3 & 22,33 \\
\hline \multirow{5}{*}{$50 \%$} & \multirow{5}{*}{$\begin{array}{c}\text { May 26, } \\
2016\end{array}$} & \multirow{5}{*}{$\begin{array}{c}\text { June } 23 \text {, } \\
2016\end{array}$} & 189,3 & 18,93 \\
\hline & & & 201,4 & 20,14 \\
\hline & & & 199 & 19,9 \\
\hline & & & 197,8 & 19,78 \\
\hline & & & 202,3 & 20,23 \\
\hline \multicolumn{3}{|c|}{ Average of Compressive Strength } & 197,9 & 19,79 \\
\hline \multirow{5}{*}{$75 \%$} & \multirow{5}{*}{$\begin{array}{c}\text { May 26, } \\
2016\end{array}$} & \multirow{5}{*}{$\begin{array}{c}\text { June } 23 \text {, } \\
2016\end{array}$} & 225,3 & 22,53 \\
\hline & & & 193,3 & 19,33 \\
\hline & & & 183,5 & 18,35 \\
\hline & & & 199 & 19,9 \\
\hline & & & 204,1 & 20,41 \\
\hline \multicolumn{3}{|c|}{ Average of Compressive Strength } & 201 & 20,1 \\
\hline
\end{tabular}

Table 6 shows that high concentration of crushed glass particles in concrete production has decreased its compressive strength due to many factors, such as interlocking, bonding, and the aggregates compressive strength itself. Aggregate's surface characteristic affects the bond between cement paste and aggregate. Rough aggregate's surface causes a good bond while the crushed bottles has a poor bond because of the slippery surfaces.

It can be concluded that waste glass addition in concrete affected its compressive strength due to its slippery surfaces. Figure 5 shows the influence of glass variation added on concrete compressive strength.

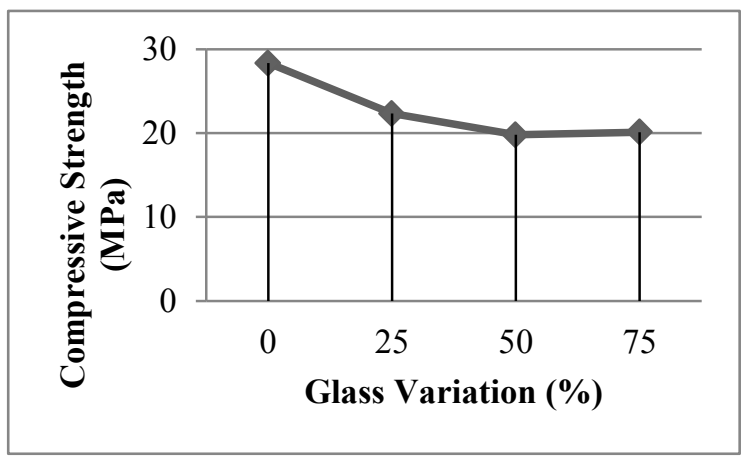

Figure 5. Influence of glass variation on concrete compressive strength.
As mentioned earlier, the concrete was designed to meet the K225 type requirements. The value of concrete compressive strength planned was $225 \mathrm{~kg} / \mathrm{cm}^{2}$ or $19 \mathrm{MPa}$. The concretes using all variations of glass concentrations did meet the requirements because it has more than 19 MPa for the all compressive strengths, namely 28,34 $\mathrm{MPa}, 22,33 \mathrm{MPa}, 19,71 \mathrm{MPa}$, and 20,1 $\mathrm{MPa}$ for $0 \%$, $25 \%, 50 \%$ and $75 \%$ of crushed brown glass bottles substitution respectively.

According to SNI-2847-2013 on Structural Concrete Requirements for Buildings, the requirements of structural concretes should not be less than $17 \mathrm{MPa}$ [5]. Structural concretes are concretesusedto withstand heavy loads, such as a building. The result of this research shows that the concretes using all variations of glass concentrations meet the requirements for structural concretes.

Table 7. Percent reduction of concrete compressive strength.

\begin{tabular}{|c|c|c|c|}
\hline $\begin{array}{c}\text { Glass } \\
\text { Variation } \\
\text { Added }\end{array}$ & $\begin{array}{c}\text { Compressive } \\
\text { Strength } \\
\left(\mathbf{k g} / \mathbf{c m}^{\mathbf{2}}\right)\end{array}$ & $\begin{array}{c}\text { Reduction of } \\
\text { Compressive } \\
\text { Strength } \\
\left(\mathbf{k g} / \mathbf{c m}^{\mathbf{2}}\right)\end{array}$ & $\begin{array}{c}\text { Reduction of } \\
\text { Compressive } \\
\text { Strength } \\
\mathbf{( \% )}\end{array}$ \\
\hline $\mathbf{0 \%}$ & 283,44 & - & - \\
\hline $\mathbf{2 5 \%}$ & 223,34 & 60,1 & 21,2 \\
\hline $\mathbf{5 0 \%}$ & 197,96 & 85,48 & 30,16 \\
\hline $\mathbf{7 5 \%}$ & 201 & 82,44 & 29,09 \\
\hline
\end{tabular}

Even if the reduction of concrete compressive strength from crushed glass particles substitution was between 20 - $30 \%$, the resulting concrete can still be used as building materials. However, if it is desired to get the same quality of a normal concrete, then it can be done by increasing the concrete compressive strength during the mix design process

\subsection{Toxicity Characteristic Procedures (TCLP)}

TCLP (Toxicity Characteristic Leaching Procedure) test was carried out in X Water Laboratory. TCLP test is used to determine leaching potential from concretes. This test was done according to TCLP Extraction Procedures for Hazardous Waste (from BAPEDAL's draft in 1992)".

TCLP test parameters can be obtained from comparing the chemical substances data with the parameters on the regulations. $\mathrm{K} 2 \mathrm{Cr} 2 \mathrm{O} 7$ were detected in one of glass bottles waste. The Appendix of Republic of Indonesia's Government Regulation Number 101 of 2014 Regarding Hazardous and Toxic Waste Management informs, $\mathrm{Cr}^{6+}$ is one of the heavy metal parameters that should be examined. The results of TCLP test can be seen in Table 8 below. 
Table 8. The results of TCLP test.

\begin{tabular}{|c|c|c|c|}
\hline No. & Sample & $\begin{array}{c}\mathrm{Cr}^{6+} \text { Level } \\
\text { (mg/lt) }\end{array}$ & $\begin{array}{c}\text { Average } \\
\text { of } \\
\mathrm{Cr}^{6+} \text { Level } \\
\text { (mg/lt) }\end{array}$ \\
\hline \multirow{2}{*}{1} & \multirow{2}{*}{$\begin{array}{l}\text { Concrete with } \\
0 \% \text { crushed } \\
\text { glass particles }\end{array}$} & 0,6 & \multirow{2}{*}{0,6115} \\
\hline & & 0,623 & \\
\hline \multirow{2}{*}{2} & \multirow{2}{*}{$\begin{array}{l}\text { Concrete with } \\
25 \% \text { crushed } \\
\text { glass particles }\end{array}$} & 0,717 & \multirow{2}{*}{0,762} \\
\hline & & 0,807 & \\
\hline \multirow{2}{*}{3} & \multirow{2}{*}{$\begin{array}{l}\text { Concrete with } \\
50 \% \text { crushed } \\
\text { glass particles }\end{array}$} & 0,691 & \multirow{2}{*}{0,6785} \\
\hline & & 0,666 & \\
\hline \multirow{2}{*}{4} & \multirow{2}{*}{$\begin{array}{l}\text { Concrete with } \\
75 \% \text { crushed } \\
\text { glass particles }\end{array}$} & 0,547 & \multirow{2}{*}{0,6185} \\
\hline & & 0,69 & \\
\hline
\end{tabular}

Table 8 shows the result of TCLP test for $\mathrm{Cr}^{6+}$ levels in the concretes using all variations of glass concentrations. It shows that the concrete with $25 \%$ glass particles has the highest concentration of $\mathrm{Cr}^{6+}(0,762 \mathrm{mg} / \mathrm{l})$. It is possibly caused by $\mathrm{Cr}^{6+}$ found within the crushed glass particles added.

The $\mathrm{Cr}^{6+}$ level, however, was decreasing with the increasing concentration of glass particles added,. which might be due to the reaction between $\mathrm{Ca}^{2+}$ of cement paste with $\mathrm{CrO}_{4}{ }^{2-}$ from the chemical substances in glass bottles waste. $\mathrm{Cr}^{6+}$ immobilization can be done with the formation of $\mathrm{CaCrO} 4$.

There were 2 quality TCLP standards used in this research. The first standard is taken from the Appendix III of Republic of Indonesia's Government Regulation Number 101 of 2014 Regarding Hazardous and Toxic Waste Management. This regulation is used to identify the category of hazardous waste. The quality standard for TCLP B requires $\mathrm{Cr}^{6+}$ concentration of less than 2,5 $\mathrm{mg} / \mathrm{l}$ and for TCLP A, the $\mathrm{Cr}^{6+}$ concentration should not be over the $15 \mathrm{mg} / \mathrm{l}$. As for the results of this study, it showed that concentrations of $\mathrm{Cr}^{6+}$ from the concretes using all variations of glass concentrations were all under the $2,5 \mathrm{mg} / \mathrm{l}$. So, it can be considered as not having toxic characteristic from $\mathrm{Cr}^{6+}$ concentration.

The second standards is the Appendix IV of Republic of Indonesia's Government Regulation Number 101 of 2014 on Hazardous and Toxic Waste Management. This regulation is used to establish the hazardous waste treatment before placing in a dumping location. The limit of quality standard is $2,5 \mathrm{mg} / \mathrm{l}$. In this research, TCLP test showed that concentrations of $\mathrm{Cr}^{6+}$ from the concretes using all variations of glass concentrations were all under the threshold of 2,5 $\mathrm{mg} / \mathrm{l}$. In accordance to these quality standards, the glass particles concretes can be safely placed in any dumping location. But, a Paint Filter Test needs to be done beforehand to finally determine whether this solidification of waste can be placed on dumping sites.

\subsection{Potential Reduction of Glass Bottles Waste}

Potential reduction of glass bottles waste was determined by counting the weight differences of coarse aggregate's and crushed glass particles. This study shows that a $75 \%$ glass particles mix used as coarse aggregates substitute can still have a good quality in terms of concrete compressive strength and TCLP test. Therefore, the concrete using $75 \%$ glass concentrations was chosen for the calculation of reduction glass bottles waste.

Table 9. Potential reduction of glass bottles waste.

\begin{tabular}{|c|c|c|c|c|}
\hline $\begin{array}{c}\text { Coarse } \\
\text { Aggregate } \\
\text { Needed } \\
\left(\mathbf{k g} / \mathbf{m}^{3}\right)\end{array}$ & $\begin{array}{c}\text { Glass } \\
\text { Needed as } \\
\text { Coarse } \\
\text { Aggregate } \\
-75 \% \\
\left(\mathbf{k g} / \mathbf{m}^{3}\right)\end{array}$ & $\begin{array}{c}\text { Bottles } \\
\text { Size } \\
(\mathrm{ml})\end{array}$ & $\begin{array}{c}\text { Bottles } \\
\text { Weight } \\
\text { (kg) }\end{array}$ & $\begin{array}{c}\text { Potential } \\
\text { Reduction } \\
\text { of Glass } \\
\text { Bottles } \\
\text { Waste } \\
\text { (Bottles) }\end{array}$ \\
\hline \multirow{4}{*}{978,99} & \multirow{4}{*}{734,24} & 500 & 0,26 & 2824,01 \\
\hline & & 2500 & 1,01 & 726,97 \\
\hline & & 2500 & 1,17 & 627,56 \\
\hline & & 1000 & 1,2 & 611,87 \\
\hline
\end{tabular}

Table 9 shows that the weight of coarse aggregate needed was obtained from mix design of this research. Potential reduction of glass bottles waste is considered to be significant. The K225-type concrete can reduce 2.825 bottles of $500 \mathrm{ml}$ bottles size. If the $2.500 \mathrm{ml}$ bottles size were used, then it can reduce up to 700 bottles, whilst as many as 612 bottles can be reduced if the $1.000 \mathrm{ml}$ bottles size are used. This research shows that subtitution of aggregates of concrete can be used to reduce used reagent glass bottles in a laboratory.

\section{Conclusions}

Several important conclusion can be taken as follows:

1. Waste glass can be used to subtitute coarse aggregates by $0 \%, 25 \%, 50 \%$ and $75 \%$ in concrete production.

2. Concretes produced using waste glass meet the concrete compressive strength of K225-type requirements, hence they can be safely used for construction.

3. The TCLP test results meet the requirements of Republic of Indonesia's Government Regulation Number 101 of 2014 Regarding Hazardous and Toxic Waste Management, indicating the concretes to be environmentally friendly.

4. The subtitution of coarse aggregates in concrete potentially reduces glass bottles waste in laboratories. The reduction of glass bottles can be up to 2.100 bottles with any kind of size and weight.

5. The reduction of these waste bottles will also reduce the cost of disposing them into a landfill. 


\section{References}

1. Aswad, N. H., \& Soeparyanto, T. S.,Glass Bottles Fractions Used as Coarse Aggregates on Concretes Mixes,Stabilita, 2(1)., (2014)

2. Damanhuri, E., \& Padmi, T.,Solid Waste Management.Environmental Engineering Book, Institut Teknologi Bandung, (2010)

3. Dipohusodo, I.,Reinforced Concrete Structures, PT Gramedia Pustaka Utama, Jakarta, (1994)

4. Hadi, G. Utilization of Glass Waste as a Substitute of Coarse Aggregates in Eco-Friendly Concretes, Thesis, Civil Engineering Department, Institut Teknologi Nasional, Bandung, (2009)

5. Indonesian National Standard,Structural Concrete Requirements for Buildings,SNI-2847-2013, (2013)

6. Indonesian National Standard, Compressive Strength Test Method, SNI 03 - 1974 - 1990, (1990)

7. LaGrega, M. D., Buckingham, P. L., \& Evans, J. C.,Hazardous Waste Management, 2nd ed.,McGraw-Hill, Singapore, (2001)

8. Republic of Indonesia's Government. Government Regulation Number 101 of 2014 Regarding Hazardous and Toxic Waste Management, (2014)

9. Sagel, R., Kole, P., \& Kusuma, G., Guideline of Concrete Constraction, Penerbit Erlangga, Jakarta, (1997)

10. Setiawan, B.,The Effect of Glass Aggregates Used on Concretes Reviewed from Concrete Strength and Shrinkage, Thesis, Petra Christian University, (2006)

11. Shi, C., \& Zheng, K., A Review on the Use of Waste Glasses in the Production of Cement and Concrete. Elsevier: Resources, Conservation and Recycling 52, pp 234-237, (2007)

12. Suhartini, A., Srie Gunarti, A. S., \& Hasan, A., The Effect of Crushed Glass Added as Fine Aggregates Subtitutes to Compressive Strength and Flexural Strength, BENTANG Journal, (2014)

13. Topcu, I. B., \& Canbaz, M., Properties of Concrete Containing Waste Glass, Cement and Concrete Research 34, pp 267-274, (2004)

14. Utomo, M. P., \& Laksono, E. W., Study of Solidification/Stabilization of Heavy Metal Process with Portland Cement, (2007)

15. Wang, S., \& Vipulanandan, C., Solidification/stabilization of Cr (VI) with Cement Leachability and XRD Analysis. Cement and Concrete Research 30, pp 385-389, (2000) 